\title{
Om Jean-Paul Sartres Kvalme og romanens paradokser
}

Kvalme udkom første gang i 1938. Det er ikke noget ligegyldigt tidspunkt, da det peger på, at romanen er skrevet på overgangen fra den tidlige højmodernisme til efterkrigstidens nouveau roman. Denne placering kan illustreres på mange måder, såvel historisk som teoretisk, og jeg skal beskæftige mig med nogle af disse. Jeg vil dog hverken begynde med teorien eller historien, men med teksten selv - med en af optegnelserne i fortællerens dagbog (det er ikke uvigtigt, at Kvalme er skrevet som en dagbog).

"Fastelavnstirsdag« er overskriften på en af optegnelserne i Roquentins dagbog. Den begynder med et mareridt, hvor Roquentin og to venner gør noget decideret vulgært med en buket violer på den ultrahøjreorienterede franske forfatter Maurice Barrès. Fra denne noget kulørte indledning skifter episoden til mere hverdagsagtige sager: modtagelsen af et brev fra elskerinden Anny, frokost på restauranten i Rue des Horloges, turen ud fra restauranten og ud på gaderne i Bouville. Optegnelsen slutter med den følgende passage:

"Regnen er holdt op, luften er mild, over himlen glider langsomt de dejligste mørke billeder: det er mere end tilstrækkeligt til at danne rammen om et fuldkomment øjeblik; for at kunne spejle disse billeder ville Anny skabe et lille dunkelt tidevand i vore hjerter. Men jeg ved ikke, hvordan jeg skal udnytte lejligheden: jeg går, tilfældigt, tom og rolig, under den ubrugte himmel«.

Passagen opstiller to kontrasterende holdninger til himlen, Annys og Roquentins. Sådan som Roquentin forestiller sig Annys gestus, vil den være

1. Jean-Paul Sartre: Kvalme, Kbh. 1963, p. 87 (herefter forkortet K). Efterfølgende sidehenvisninger henviser til denne udgave. 
"appropriativ«, dvs. den vil tilegne sig den naturlige verden i forsøget på at få den til at passe med den litterære model, som man kunne kalde 'le moment bienheureux', det lykkelige øjeblik, hentet direkte fra Prousts $A$ la recherche du temps perdu (1909-1922). Annys forvandlede himmel er en litterær himmel; den er befængt med metafor, med de litterære pendanter til forsøget på billedmæssig indramning, på samme måde som Prousts himmel er filtreret gennem formerne i Elstirs malerier, som fortælleren til gengæld - i en lukket cirkelbevægelse - søger at udfolde i en litterær version. Roquentins himmel er fuldstændig anderledes: den er tom slet og ret, den åbner sig ikke for metaforisk tilegnelse. Den forbliver »inutilisé« - ubrugt. Men hermed melder der sig også et problem. Udtrykket en 'ubrugt himmel' er selv metaforisk. Det negative præfix er selvfølgelig beregnet på at negere den trøsterige, følelsesmæssigt nyttige ordning af den naturlige verden, som bliver tilvejebragt af metaforen. Dette indebærer imidlertid et paradoks, hvor Roquentin bruger metaforen til at afvise metaforen. Jeg skal mere detaljereret vende tilbage til spørgsmålet om metaforen i Kvalme (som i øvrigt er hovedtemaet i Robbe-Grillets kritik af Sartres roman). Her og nu vil jeg nøjes med at bruge eksemplet til at illustrere et mere generelt paradoks, for det er omkring dette paradoks, at de fleste interessante spørgsmål til Kvalme drejer sig. Kvalme er en bog, der hævder, at bøger er værdiløse, fordi de kommer med det inautentiske livs stereotype formler; de tilbyder former og alibier for måder at leve på, som med Sartres eksistentialistiske moralbegreber må anskues som udtryk for 'mauvaise foi' - uredelighed. »Det forekommer mig, at alt, hvad jeg ved om mit liv, det har jeg lært i bøgerne« $(K$, p. 80), bemærker Roquentin, hvorved han underforstår, at den omtalte 'viden' er ganske bedragerisk, og at vi derfor ville gøre klogest $i$ helt at se bort fra den. Men på den anden side kender vi som læsere kun denne påstand, fordi Roquentin har indført den i sin dagbog, eller - mere pertinent - fordi den optræder i en bog af Jean-Paul Sartre. Hertil kommer det, som måske er en af de finere ironier i den skæbne, Kvalme har fået: At denne bog, som højlydt proklamerer, at vi ikke skal leve vores liv gennem bøger, blev både myte og model for en hel efterkrigsgeneration. Den hyppighed, hvormed intellektuelle, og ikke kun på de parisiske boulevarder og cafeer, fik anfald af kontingens-syge må utvivlsomt delvis tilskrives det forhold, at de havde læst Kvalme. (Denne side af sagen er i øvrigt parodieret i Boris Vians meget morsomme roman L'Écume des jours (1947) (dansk: Dagenes skum (1966)), hvor en af personerne demonstrerer en morbid begejstring for forfatteren Jean-Sol Partre, forfatter til den indflydelsesrige roman Brak og det filosofiske essay Opstødets paradokser). 
Romanen myldrer således med paradokser i flere retninger, og jeg skal senere komme ind på endnu nogle stykker. Deres generelle form skulle imidlertid være klar nu, og dertil også velbekendt som et af vartegnene i den moderne romans landskab som helhed: De peger på det paradoks, at den moderne roman i selve sit anlæg problematiserer eller simpelthen afviser den genre, den selv tilhører. I den henseende skal man også huske, hvornår Kvalme udkom: 1938. Ud fra flere perspektiver er det et signifikant tidspunkt. Måske det mest velkendte perspektiv - selv om det på mange måder er utilfredsstillende - er det, som søger at relatere Kvalme til de filosofiske temaer (overvejende fænomenologiske og eksistentialistiske), som Sartre på dette tidspunkt var optaget af, og som kulminerede i det, der for mange er Sartres magnum opus: L'Étre et le néant (1943). Det er et perspektiv, som rejser en række potentielt interessante spørgsmål om, hvorvidt tyngdepunkterne i den filosofiske ambition er af en sådan art, at de aktivt styrer den litterære udtryksform, eller om de omvendt strider imod denne: som eksempel kan nævnes det, vi kunne kalde driften mod 'det narrative' i L'Etre et le néant, som udspringer af de detaljerede fænomenologiske adfærdsbeskrivelser, som Sartre eksplicit sætter som metodologisk afgørende for den filosofiske virksomhed som sådan. På den anden side er der det argument, som hævder en fundamental spænding eller 'dissonans' mellem påstandene i den eksistentialistiske doktrin og de basale genrekrav i den fortællende kunst: bredt sagt, uoverensstemmelsen mellem på den ene side det eksistentialistiske udsagn, at verden er absolut kontingent og individet absolut frit, og på den anden side de foregribende og prækluderende operationer, som er vitale for alt hvad vi med nogen plausibilitet kan erkende som narrativ struktur. Disse spørgsmål vil jeg vende tilbage til. For indeværende vil jeg nøjes med den meget mere begrænsede pointe; at det ikke forekommer at være nogen særlig nyttig øvelse at diskutere Kvalme, sådan som det så ofte er gjort, dvs. som en fiktionaliseret version af en serie af filosofiske temaer; betingelserne for en sådan diskussion reducerer effektivt Kvalme til en rent instrumental status - til en slags tjenestepige for en anden diskurs - og giver ikke nogen ramme for at stille det langt vigtigere spørgsmål om romanens status som fiktion.

Ud fra et litteraturhistorisk synspunkt er året 1938 ikke uinteressant. Groft sagt befinder Kvalme sig midtvejs mellem de former for narrative eksperimenter, som vi forbinder med Proust og Gide, og de eksperimenter som senere dukkede op under den kollektive, men fundamentalt polemiske overskrift nouveau roman. Selvom mit ærinde her ikke er at spore påvirkninger, hverken bagud eller fremad, så antyder udgivelsesåret for Kvalme en placering i en overgangsfase ved romanens indtræden i det Nathalie Sarraute har kaldt 'mistænksomhedens tidsalder'. Kvalme er udformet over en erfaring 
med det, man kunne kalde generaliseret epistemisk ængstelse, et tab af sikkerhed i de kendte mønstre for viden og forståelse, og inden for dette bliver romanen selv, og de tankemodeller, den karakteristisk understøtter, en privilegeret genstand for 'mistanke'. Romanen er ikke længere et selvfølgeligt redskab for undersøgelse og opdagelse. Dens hermeneutiske legitimitet er ikke længere uproblematisk, som den var for Balzac, da han sagde, at romanen gav den højeste adgang til virkelighedens sens caché. Kort sagt er romanen ikke længere en troværdig guide til noget som helst, måske lige bortset fra dens funktion som guide til al tings absolutte upålidelighed (hvis den vel at mærke er skrevet på en bestemt måde - hvad franskmændene nu om dage ville kalde en 'dekonstruktiv' måde). Sartres roman placerer sig centralt inden for denne problematik. Men et aspekt, der giver den en særlig interesse, er, at dens procise placering er noget usikker. Dens position er tvetydig i forhold til det skeptiske paradigme og de mangfoldige paradokser, som dette paradigme genererer. Mit hovedærinde i det følgende er en diskussion af, hvordan Kvalme forholder sig til denne tvetydighed, og hvilken bevidsthed den udviser om arten af denne tvetydighed og dens følger.

I den forbindelse kunne vi måske begynde med at citere en anden af Sartres metaforer eller rettere: analogier. Sartre bemærkede engang, at en stor roman inter alia ville være som en sten. Det lyder ikke som et lovende udgangspunkt for grundlæggelsen af et nyt narrativt program; ja, det lyder umiddelbart, som om det overhovedet ikke giver nogen mening. Men her skal vi huske, at sten (og deres varianter, småsten, kampesten, klippestykker) har spillet en stor og stærk rolle i meget af den moderne franske tænkning. Sten har selvfølgelig også en central betydning i Kvalme, hvor Roquentin rammes af sit første anfald af eksistentiel kvalme, da han samler en sten op på stranden ('den sten', husker han senere, 'var begyndelsen til hele dette forbandede forløb'). Sten er også det afgørende element i Camus' allegori over det absurde, hans brug af historien om Sisyfos, hvis gentagne, men mislykkede forsøg på at rulle stenen op af bjerget illustrerer den evige modsætning mellem det menneskelige begær efter mening og verdens modstand (hvilket i forhold til Kvalme vil sige modsætningen mellem begæret efter 'historie' og angsten for 'kontingens'). Hvis vi forbliver i denne kontekst af specifikt litterær teori og praksis, dukker vores sten eller småsten op i mindst to andre, vigtige sammenhænge. For det første i Valérys glimrende, om end nu om stunder lidet læste, imaginære sokratiske dialog Eupalinos (1923) (på dansk: Tre Dialoger (1946)). Valérys Sokrates samler stenen op, mens han går langs kysten. Havet har gennem århundreder skyllet hen over stenen, og den er blevet fuldkommen glat og rund. Den rejser spørgsmålet om, hvorvidt en fuldkommenhed, der er skabt af tilfældige naturkræfter, meningsfuldt kan sammenlignes med fuldkommenheden i et kunstværk. 
Sokrates' svar er et emfatisk 'Nej', idet han henviser til, at fuldkommenheden er tilfældig, et resultatet af kontingente kræfters spil, hvorimod vilkåret for det æstetiske artefakt er det menneskelige sinds og den menneskelige hånds bevidste, ordnende aktivitet. Det andet eksempel, jeg vil trække frem, er Francis Ponges korte, men kun tilsyneladende enkle prosadigt 'Le Galet' (eller 'Strandstenen'). Ponges strandsten er også fuldkommen, men den har en tvetydig status. Det er ikke klart, om det virkelige objekt for Ponges opmærksomhed er tingen selv eller det ord, 'galet, som betegner den; hans digt svinger tvetydigt og ironisk frem og tilbage mellem sprogets referentielle og selvreferentielle funktioner, idet det overfladisk set mimer tingens materielle egenskaber, mens det i virkeligheden undersøger og leger med ordets materielle egenskaber. Snarere end at navngive tingene, tingsliggør det navnene. Det er en omhyggeligt opdyrket tvetydighed, der har vidtrækkende implikationer. Den rejser på sin egen nedtonede måde karakteristiske 'modernistiske' spørgsmål til muligheder og begrænsninger i forholdet mellem sprog og virkelighed.

Det ser således ud til, at sten ofte dukker op i den moderne litterære bevidsthed i Frankrig. Men Sartres romanagtige sten eller stenagtige roman er ganske forskellig fra stenene hos såvel Valéry som Ponge. Sartre tænker på noget helt andet end Ponges tvetydige spil mellem referentialitet og selvrefleksion, og også noget helt andet end Valérys strenge klassiske insisteren på den ordnende kraft i fantasi og konvention. I virkeligheden forestiller Sartre sig en usædvanligt naiv version af en meget naiv og traditionel mimesisteori. Han forestiller sig en roman, der skal ligne stenen i dens rene kontingens, en roman så uselvbevidst, så befriet for kunstfærdighed og konvention, at den vil give os et umedieret billede af tingenes rå kaos, verden i dens rene, meningsløse 'Dasein'. Det er selvfølgelig en fantasi. Det er et helt åbent spørgsmål, hvordan sådan en roman kunne tænkes at se ud og, mere relevant, i hvilken udstrækning Kvalme kunne analyseres forståeligt ud fra dette program.

Ikke desto mindre er en stor del af Kvalme organiseret omkring en fantasi af denne art. I første række fordi det, som ligger til grund for den, lige præcis er følgerne af Roquentins kvalmeerfaring. Symptomerne på og konsekvenserne af Roquentins kvalmeøjeblikke - med strandstenen, med ølglasset, med træroden osv. - er ofte blevet diskuteret, og jeg vil ikke give en detaljeret gennemgang af denne diskussion her. Ej heller vil jeg diskutere deres filosofiske kontekst (den eksistentialistiske teori om kontingens) eller det synspunkt, at de ikke så meget repræsenterer et filosofisk perspektiv som en psykiatrisk tilstand; de positive helbredsmæssige implikationer af det sidstnævnte perspektiv er, at alle Roquentins problemer kunne behandles på en passende måde, hvis han gik til en god læge, men i forhold til dette 
giver romanen selv et svar med figuren Dr. Rogé, Erfaringens og Visdommens stemme, hvis visdom består i 'at forklare det nye ved hjælp af det gamle'( $K$, p. 85) Men helt generelt er Roquentins kvalme det symptomatiske udtryk for alle vante referencerammers bortfald. Dette medfører ophævelsen af forskelle, sammenbruddet for al klassifikation og udviskningen af distinktive træk, alt sammen i en proces hvor identiteter flyder sammen og danner en blød, geleagtig masse, hvor det ikke længere er muligt at skelne struktur eller mening. Med Roquentins ord betyder kvalme, at "verden af menneskelige mål' forsvinder, at 'de svage orienteringspunkter, som mennesker har sat på tingenes overflade' viskes ud. Kvalme er beslægtet med en oplevelse af, at det hele 'smelter': 'Nu var denne fernis smeltet bort, og tilbage var nogle uhyre masser, kraftløse, uordentlige - nøgne, med en obskøn og skræmmende, nøgenhed' (K, p. 151) Eller med Roquentins aurale metafor er verden ikke så meget et lager for informationer, en kilde til budskaber, som vi trygt kan afkode, men snarere et sted præget af 'summen, blottet for enhver betydning'( $K$, p. 103).

Inden for denne generaliserede opløsning af alle menneskelige ordens- og repræsentationssystemer er der imidlertid ét, som underkastes en særlig hårdhændet behandling: fortællingens system. 'Fortællinger' ('historier') er på én gang rekvisitter og masker; de støtter os, de gør verden beboelig, ved at gøre os blinde for eksistensens rene overflødighed, det umotiverede eller (i Sartres noget mere moralistiske termer) det 'uberettigede' i vores væren-iverden. Ud fra dette synspunkt er nøglen til Kvalme den følgende passage; den er lang, men værd at citere in extenso.

"Her er, hvad jeg tænkte: for at den mest banale begivenhed kan blive til et eventyr, er det nødvendigt og tilstrækkeligt, at man giver sig til at fortælle den. Det er det, der narrer folk: et menneske er altid en historiefortæller, han lever omgivet af historier, sine egne og andres historier, han ser alt, hvad der sker ham, gennem dem, og han søger at leve sit liv, som om han fortalte det.

Men man må vælge: enten at leve eller at fortælle. For eksempel da jeg var i Hamburg, sammen med Erna, som jeg ikke stolede på, og som var bange for mig, førte jeg en besynderlig tilværelse. Men jeg var i den, og jeg tænkte ikke på den. Så en aften i en lille café i Sankt Pauli gik hun fra mig for at gå på toilettet. Jeg blev siddende alene, der var en grammofon, der spillede Blue Skies. Jeg begyndte at fortælle mig selv, hvad der var sket siden min ankomst. Jeg sagde til mig selv: »Den tredje aften gik jeg ind i en restaurant kaldet »Den blå grotte« og fik straks øje på en stor, halvfuld pige. $\mathrm{Og}$ det var netop den pige, jeg sidder og venter på i dette øjeblik, mens jeg lytter til Blue Skies, og som vil komme tilbage og sætte 
sig på min højre side og lægge sine arme omkring halsen på mig.« Da følte jeg voldsomt, at jeg havde et eventyr. Men Erna kom tilbage, hun satte sig ved siden af mig, hun lagde armene om halsen på mig, og jeg afskyede hende, jeg vidste ikke hvorfor. Jeg forstår det nu: det var, fordi jeg igen måtte begynde at leve, og indtrykket af eventyr forduftede.

Når man lever, sker der ingenting. Omgivelserne skifter, mennesker kommer og går, det er det hele. Der er aldrig tale om nogen begyndelse. Dage føjer sig til dage uden mening eller hensigt, det er en uendelig og monoton opregning...Der er heller ingen slutning: man forlader aldrig en kvinde, en ven, en by på én gang...

Det er at leve. Men når man fortæller om livet, forandrer alt sig; kun er det en forandring, som ingen bemærker: beviset er, at man kan tale om sande historier. Som om historier kunne være sande; begivenheder sker i én retning, og vi fortæller om dem i den modsatte retning ...

Jeg har villet, at øjeblikkene i mit liv skulle følge hinanden og ordne sig som i det liv, man erindrer sig. Jeg kunne lige så godt have forsøgt at gribe tiden ved halen« $(K$, p. $51 \mathrm{ff})$.

Det vigtigste i dette syn på fortællingen ligger i modsætningen mellem to begreber: Begivenhed (évènement) og Eventyr (aventure). Der er blevet sagt meget om denne distinktion, dels fordi den har berøringsflader til Sartres filosofiske skrifter, dels fordi den har forbindelse til genkommende problemer i det 20. århundredes narrative teori. Anliggendet er, i hvert fald overfladisk set, ret enkelt. 'Begivenheder' er det, som sker i det virkelige liv; 'eventyr' er det, som sker i bøger (skønt de også kan indtræffe i det virkelige liv i samme grad som vi modellerer vores liv efter bøgerne). Begivenheder konstituerer frit-flydende, udeterminerede, diskontinuerte serier af 'tingder-sker'. Omvendt er eventyr ting-der-sker, som føjes ind i en betydningsfuld orden, en kausal sekvens, et meningsfuldt mønster; kort sagt er eventyr lig med begivenhed plus forståelighed.

Den forståelighed, som her er på tale, er basalt af tidsmæssig karakter. Tiden anskuet som begivenhed er tid i dens 'løse hverdagsagtighed', hvor 'dage føjes til dage uden rytme eller ræson', som 'en endeløs, monoton addition'. Eventyrets tid, derimod, er tid ‘som griber sig selv i halen'. Den har i overensstemmelse med Aristoteles' formel en begyndelse, en midte og en slutning, den rummer varsler og løsninger, den foregriber og den lukker. $\mathrm{Og}$ først og fremmest er denne tid organiseret ud fra en signifikant afslutning. Erfaring har i sine narrative udgaver en teleologisk struktur, hvor det, som kommer før, er determineret af det, som kommer efter - i fortællingens verden er det sådan, at 'slutningen, som forandrer alt, er allerede tilstede'. I fortællingen er alting så at sige tilbage ved begyndelsen: livet som fortælling 
er et liv, der 'går sin gang i bagvendt orden: de enkelte øjeblikke er hørt op med at hobe sig op tilfældigt, det ene oven på det andet, de er blevet grebet af historiens slutning, som trækker dem til sig, og hvert enkelt af dem trækker på sin side det foregående øjeblik til sig' $(K$, p. 53).

I denne sammenfletning af bemærkninger kan vi læse forudsætninger for Roquentins (og Sartres) kritik af fortællingens præsuppositioner og procedurer. Fortællingen (eller eventyret) påtvinger erfaringens kontingente uorden en kunstig orden, den giver en artificiel mening til det, som i følge sin natur er uden mening; den tilskriver mønster og formål til det, som er formløst og overflødigt. Fortællinger er kort sagt epistemologiske bondefangerkneb. Som sådan er der næppe noget nyt i dette sæt af påstande - vi finder stort set de samme ideer i f.eks. Gides begreb om fortællingen som 'falskneri' eller 'bedrageri', hvortil kunne føjes et større antal andre kilder (som slet ikke behøver at være at være begrænset til at skulle bevare 'modernismen', selv om man ofte polemisk eller fejlagtigt tillægger dem denne funktion). Når Sartres version af dette særlige emne har en særlig kant og en særlig presserende karakter, skyldes det, at han ikke begrænser sig til rent epistemologiske undersøgelser. Eller rettere: den epistemologiske tvivl om fortællingens legitimation er tæt forbundet med betragtninger af social og ideologisk karakter. Fortællinger, narrative mønstre, er ikke kun kilder til epistemologiske fejl; de er også kilder til uærlighed (eller med Sartres udtryk: 'mauvaise foi'). Fiktioner indviet af Fiktion tjener miskrediterede, utilitaristiske formål. For vi nøjes ikke med at genfortælle eller lytte til 'historier': vi bliver opmærksomme på os selv og andre, vi arrangerer vores liv og vi konstruerer vores verdener i overensstemmelse med historiernes komfortable og betryggende dispositioner: 'et menneske er altid en historiefortæller, han lever omgivet af historier, sine egne og andres historier, han ser alt, hvad der sker ham gennem dem; og han søger at leve sit liv, som om han fortalte det' $(K$, p. 51). Det som understreges i denne bemærkning - og som understreges igen og igen i de ideologiske argumenter, som senere omgiver le nouveau roman - er det, som er blevet kaldt skriftens 'socialitet'. Dette skal ikke blot forstås traditionelt som den sociale determinering af litteraturen, men også i den mere aktive betydning, at litteraturen selv intervenerer i den social konstruktion af virkeligheden; altså litteraturen som direkte medvirkende i udformningen af de overenskomster og arrangementer, hvorigennem vi kollektivt skærer en arbitrær orden til, som om det var tingenes naturlige orden. (I Kvalme er paradigmet på denne ideologiske og kulturelle konspiration billedgalleriet viet til portrættet af Bouvilles notabiliteter).

Roquentins liv repræsenterer en samlet og forpint bestræbelse på at undgå historiens lokketoner for i stedet at konfrontere virkeligheden i dens ikke-narrative 'nøgenhed', den 'obskøne nøgenhed', som viser sig for 
blikket, når alle de menneskelige fiktioners 'politur' er 'smeltet' væk. Vanskeligheden i dette i øvrigt modige projekt (hvis vi godtager dets forudsætninger) er, at Roquentins 'liv' for os netop er et fortalt liv, direkte i form af hans dagbog og indirekte som en 'roman' skrevet af Sartre. Og spørgsmålet er selvfølgelig: hvordan placerer vi denne historie i forhold til den devaluering af historien, som Roquentin selv fremfører? Angår beskyldningen om mauvaise foi kun en bestemt klasse af fortællinger (som Sartres fortælling er undtaget fra, fordi den giver os noget radikalt forskelligt fra traditionen; eller angår denne alle former for fortælling som en disposition, der ligger i fortællingens natur eller endnu bredere i et ethvert artikuleret udsagn om verden? Er Kvalme en bog, der forbliver tro over det, som kvalmen implicerer? Eller er betingelserne for argumentet sådanne, at de gør en sådan fordring selvmodsigende? Og hvis det sidste er tilfældet, er det et spørgsmål, i hvor høj grad, Kvalme er bevidst om dette paradoks? Man kunne reducere alle disse spørgsmål til en slags formel: er Kvalme 'sten' eller 'historie'? Eller, mere præcist, repræsenterer dette sæt af alternative scenarier et sæt af realistiske valgmuligheder?

Hvis vi følger sten-metaforen (dvs. tanken om en roman uden mauvaise $f o i$, der overgiver sig til verdens kontingens), så vil vi selvfølgelig ende med noget (om end det er uvist med hvor meget). Vi kan f.eks. pege på det kunstgreb (device), som man kunne kalde historien-der-smuldrer; f.eks. i den tidligere citerede passage historien om kvinden fra Hamburg, Erna, rekonstrueret som Eventyr og derefter dekonstrueret som Begivenhed, med den sidste version som en udviskning af forudsætningerne for den første version. $\mathrm{Og}$ vi kunne pege på visse måder at håndtere tiden på, som er gjort mulige gennem manipulation af dagbogens konventioner. Der er den narrative ubestemthed i den udaterede 'første' optegnelse og den futurum, hvormed Roquentins manuskript slutter ('I morgen vil det regne over Bouville'). Der optræder hyppige skift i tempus på en måde, som antyder en vis sammensmeltning af fortalt tid og fortælletid, jfr. f.eks. episoden i den parisiske restaurant: 'Da jeg følte mig træt, gik jeg lige ind i en café og satte mig til at sove. Tjeneren har lige vækket mig, og jeg skriver dette i halvsøvne' $(K$, p. 183) Denne strategi med skiftende temporale perspektiver er tydeligvis udformet med henblik på at fremmane et liv, som det leves; i stedet for den klassiske, bydende narrative præteritum, der, som Roland Barthes har udtrykt det, konverterer liv til 'skæbne' ('aventure'), ser vi her et forsøg på at få skriftens rytmer til at stemme overens med teksturen i selve den eksistentielle virkelighed - hvori fortid, nutid og fremtid, erindring, erfaring og projekt ikke får mulighed for at falde til ro i arrangerede mønstre.

Endelig kunne vi måske citere visse kritiske erfaringer med og i sproget: den berømte hændelse med træroden i den offentlige park, hvor dette 
primære redskab for differentiering og klassificering, navngivningens princip, bryder sammen: Som Roquentin udtrykker det: 'Tingene har løsrevet sig fra deres navne ... jeg er midt imellem tingene, de unævnelige' $(K, \mathrm{p}$. 149). Det følger af dette, at tingene, hvis de afklædes de menneskelige og menneskeliggørende etiketter, som sproget hæfter på dem, vil vise sig for Roquentin i deres oprindelige, ontologiske tilstand som ren kontingens. En tilsvarende implikation kunne man finde i de hallucinerede sekvenser i Kvalme, f.eks. den episode, hvor Roquentin strejfer om i gaderne i en halvvejs dement tilstand efter at han i avisen har læst om pigen, der er blevet stranguleret og voldtaget); i sammenfletningen af kendsgerninger og fantasi kommer syntaksen selv under pres: sætningerne yngler og bryder sammen på samme tid, i en vild udveksling af subjekter og prædikater, der ikke længere er i stand til at holde sammen på det system af identitet og differens, som alene kan give den tryghed og trøst, der ligger i en forstålig virkelighed.

Alt dette er eksempler på en fortælling, der prøver at undgå den traditionelle histories mauvaise foi, samtidig med at den søger efter en ny form for narrativt autenticitet. Men det er lige præcis på dette punkt, at vi støder ind i alle de kritiske paradokser, som allerede er blevet omtalt. De punkter, jeg har henvist til, kunne anses for figurer i forsøget på at dramatisere eksistensens meningsløshed, men de er ikke selv meningsløse. De giver mening, om ikke til andet så til denne meningsløshed, på samme måde som det at tale om tingenes ubenævnelighed stadig er at navngive dem (om så blot som 'Unævnelige' - det paradoks, som Becketts L'Innommable kredser om i en uendelighed). Det vil sige, at det sproglige og litterære apparat i Kvalme ikke er ligesom den sten på stranden, som samles op af Roquentin eller af Valérys Socrates. Dens elementer er ikke tilfældige og kontingente, men skabt af menneskelige valg gjort inden for et unikt menneskeligt medium. De er kunstgreb (i den stærke betydning som dette begreb har hos de russiske formalister) der er beregnet på at skabe bestemte indtryk og virkninger. Et intenderet indtryk er selvfølgelig hvad det vil sige at opleve verden som ren kontingens; men de er ikke selv kontingente. Tværtimod er de elementer i et retorisk og narrativt repertoire, ligesom alt andet i Kvalme. Måske kunne man gøre dette paradoks lidt klarere ved at vende tilbage til tekstens brug af metafor.

Det kan overraske, at en tekst, der som Kvalme i sit anlæg synes at kræve en systematisk eliminering af metaforer, er mættet med metaforer. Hvad skal vi f.eks. mene om de avisstumper, der beskrives som 'svanebjerge' $(K$, p. 121) eller Adolphes seler, der har en 'fåreagtig stædighed' ( $K$, p. 29)? Er det simpelthen, som Robbe-Grillet mener, en Sartre, der ureflekteret gør sig skyldig i den antropomorfisme, som han ud fra sine egne argumenter burde 
afvise? I en ret sofistikeret redegørelse for Sartres metaforer fremsætter Fredric Jameson det synspunkt, at Sartres metaforer reelt er 'falske metaforer'. Med dette mener han en proces af overdrivelser, der underminerer den metaforiske repræsentations traditionelle fordringer og implikationer; gennem brugen af hyperbler og gennem overlagt overdrivelse i metaforiseringen opløser og nedbryder Sartre metaforen; gennem selve denne excess peger den på sig selv som metafor, som en litterær konstruktion, hvis litteraritet markerer dens afstand til virkeligheden. Det klassiske eksempel er den elaborerede billedstruktur opbygget omkring episoden med træroden:

"....denne lange døde slange for fødderne af mig, denne slange af træ. Slange eller negl eller rod eller rovfugleklo, det var ligegyldigt ... denne tykke, rynkede klo ... denne kompakte og hårde, sælagtige hud ... en lille sort pøl for mine fødder ... en grådig klo, som sønderriver jorden og flår sin føde fra den’ ( $K$, pp. 153-58).

I denne kontekst er metaforen 'falsk' for så vidt vore forventninger om dens udtrykskraft konstant skuffes; de danner figurer, som er dramatiske, men impotente, en serie af figurer, hvor den ene afløser den anden, men hvor alle, individuelt eller kollektivt, kredser omkring det, som de aldrig kan udtrykke. Det er det figurative sprog, der danser omkring et fravær trærodens eksistentielle realitet (dens 'overflødighed') som metaforisk diskurs (og som heller ingen andre sproglige former) aldrig kan drage nytte af. Det er en interessant argumentation, og den kan hjælpe os til at finde en mening i nogle af Sartres mere barokke påhit. Men den har imidlertid en uberettiget implikation. Ifølge dette synspunkt fører den metaforiske exces i Kvalme os ikke kun til at sætte en virkelighed 'hinsides' metaforen (eller hinsides sprogets humaniserende tilegnelse af verden), men skaber også muligheden for, at vi via denne exces når en direkte kontakt med virkeligheden selv; når metaforen således undermineres, gives der plads for en forvandling af fraværet til nærvær. Således aner vi, som Jameson udtrykker det, 'på en eller måde' i eksemplet med roden - 'hinsides' dens forskellige figurative repræsentationer, der er så barokke, at de går i stumper og stykker for øjnene af os - dennes virkelighed som ren, fysisk substans. Men dette holder ikke, som det jo også fremgår af den uro, der er impliceret i det impressionistiske udtryk 'på en eller anden måde'. Hverken hos Sartre eller hos andre findes der i metaforen et 'hinsides', som teksten giver adgang til;

2. Jfr. kapitle »Transformations", in Fredric Jameson: Sartre. The Origins of a Style (org. 1961), New York 1984, p. 89-110. 
ideen om at teksten skulle føre os til en ikke-tekstlig virkelighed er selvmodsigende. Hvis metaforen i Kvalme, som Jameson foreslår, fungerer som erstatning for det, der ikke på anden måde kan bencevnes, så er der for læseren af Sartres tekst simpelthen ikke mere at sige om den sag. Metaforen er grundlaget for det, vi gør, når vi læser; vi holdes fast inden for tekstens metaforiske spil, fordi vi ikke kan bevæge os andre steder hen, måske bortset fra bevægelsen ind i tavshed. For nu at tage det centrale, mest udvidede eksempel i teksten, så kan vi læsere kun vide, hvad der følger med oplevelsen af 'kvalme' ved at blive fortalt, hvad den ligner (what it is like) - dvs. gennem et sæt af metaforiske repræsentationer, der netop har 'kvalme' som nøgleterm. 'Jeg behøver ikke at bruge blomstrende fraser', bemærker Roquentin, 'Jeg skriver for at bringe visse omstændigheder på det rene. Det gælder om at tage sig i agt for litteraturen' (K, p. 71). Men et afsnit senere finder vi ham i færd med at skrive, at 'den næste dag havde jeg en voldsom kvalme, som om jeg var vågnet op i en seng fyldt med opkast'. Dette udsagn kan næppe kaldes 'blomstrende', men det er lige så ubetvivleligt litterært som hele teksturen i Kvalme.

Virkeligheden i Kvalme er litteraturens og ikke eksistensens virkelighed. Individuelle historier kan smuldre hen, men der fortælles en generel historie (Roquentins liv) på måder, der ikke massivt krænker os i vore standardforventninger til forståelighed. Der sættes afgjort spørgsmålstegn ved tiden, sådan som vi sædvanligvis oplever den, men lige så afgjort er det, at tiden ikke forsvinder. (Rent faktisk er der i Kvalme flere eksempler på den slags litterær foregribelse, som ikke burde være der i følge den eksistentielle kritik. Det gælder f.eks. de antydninger, som kulminerer i afsløringen af Autodidaktens homoseksualitet.) Man kan få metaforen til at opføre sig på besynderlige, dekonstruktive måder, men også da opfører den sig som en metafor. Syntaksen - såvel i streng grammatisk forstand som i løsere narrativ forstand - kan trues ved visse koblinger, men den falder aldrig helt fra hinanden. Hovedpointen med disse konstateringer er ikke at hævde, at Kvalme i sidste instans er en tryg, traditionel roman, hvilket ville være en tosset påstand, Nej, pointen er, at i disse tider, hvor striden mellem traditionalister (the Ancients) og modernister (the Moderns) er præget af rigide modsætninger, er det sådan, at de omdiskuterede almene kategorier ikke simpelthen kan kollapse, selv om de både kan blive tvetydige, pressede eller udvidede på forskellig vis. Uden disse egenskaber ville fortællingen være ligesom den verden, der af Roquentin beskrives som: 'en summen, blottet for betydning'. Dette kan muligvis være god eksistentialistisk epistemologi, men det er tvivlsomt, om skriverier baseret på en sådan formel ville kunne holde ret længe på vores opmærksomhed. En tekst, der er 'en summen uden sammenhæng' kan være mange forskellige ting (f.eks. kan den på en måde 
være ligesom en sten), men den ville ikke være en tekst. Det skulle nu være klart, hvor alt dette fører os hen. Som Kermode siger: Det kan være, at sandheden om verden er kontingens, men det er ikke sandheden om fortællingen og ikke fortællingens virkelighed; for at der kan gives fortællinger må de som konstitutionsbetingelser for deres eksistens besidde egenskaber, som en kontingensteori frakender verden. ${ }^{3}$

Et svar på dette dilemma kunne være at afskaffe fortællingen eller - mere radikalt, da dette argument i sin yderste konsekvens vedrører sproget selv, at påbyde tavshed. Dette er faktisk et af de alternative valg, som Roquentin krast formulerer i sætningen: »Man må vælge: leve eller fortælle«. Sartre har imidlertid valgt at fortælle, og det samme gør Roquentin, hvis exit fra romanen er udformet som en indtræden i det litterære kald. Hvad vi helt præcis skal stille op med Roquentins beslutning om at skrive, står mig uklart. Der kunne være tale om intenderet ironi: Roquentins vending mod litteraturen som middel til personlig frelse er en kryben udenom modelleret over den proustske fortællers apoteose, ligesom Annys (latterliggjorte) filosofi er modelleret over »det fuldkomne øjeblik« i den proustske epifani. Men det kunne på den anden side også forstås lige ud ad landevejen, hvor det da ville implicere Sartres tro på en form for litterær bevidsthed og litterær praksis, der er hævet over mauvaise foi. Man kan have en mistanke om, at det sidste er tilfældet; Sartre synes ligeså involveret som Roquentin selv i dennes tale om 'frelse'. Vanskeligheden ligger i at sætte denne beslutning i forhold til den logik, der bestemmer Roquentins krav om, at vi skal vælge mellem de uforsonlige modsætninger: 'at leve' eller 'at fortælle'. Ja, lige netop de termer, hvormed Roquentin formulerer sit litterære projekt klinger mærkeligt sammen med det, han tidligere har bestræbt sig på at fremhæve: 'En anden slags bog ... For eksempel en historie af den slags, som ikke kan ske, et eventyr ... En bog. En roman ...' (K, p. 209) 'Historie'? 'Eventyr'? 'Roman'? - dette er selvfølgelig lige nøjagtig de termer, der tidligere indgik i hans angreb på menneskets mytemageri, men som nu dukker op igen som hovedpunkterne i et godkendt, bekræftet og positivt litterært program, et program som vil 'få folk til at skamme sig over deres eksistens'. Men hvordan vil denne 'anden slags bog' være forskellig fra de bøger, som han tidligere undsagde? En yderligere vanskelighed i dette er, at vi får meget få detaljer om, hvad dette program i praksis vil involvere. Nøglen her er analogien med jazzsangen 'Some of these Days', som han ikke kan få ud af sit hoved. Men trods nogle metafysiske mumlerier om at transformere 'eksi-

3. Frank Kermode udvikler denne argumentation i The Sense of an Ending, New York, Oxford and London 1966, hvor kapitlet »Literary Fiction and Reality« rummer en diskussion af Kvalme. 
stens' til 'væren' er analogien ikke synderligt oplysende. Hvad er det da, som gør den til noget særligt? Og i særdeleshed, hvorfor tilskrives jazzmelodien 'forløsende' og 'rensende' kraft, mens den 'trøst', som Roquentins tante efter sin mands tidlige død finder i Chopins Prceludier, kun fylder ham med væmmelse? Hvad gør jazz autentisk og Chopin falsk? Holder distinktionen virkelig inden for den argumentation, der bærer Kvalme, eller er der her et element af særbehandling? Er det sådan, at Chopin afvises, fordi han er en del af den kulturelle bagage, af bourgeoisiets dagligstuemytologi, mens 'Some of These Days' fejres, fordi den tilhører outsiderkulturens mere marginale og informelle miljø?

Reelt forholder det sig sådan, at hypostaseringen af jazzmelodien ganske enkelt forskyder snarere end løser det problem, som rejser sig for såvel Roquentin som for læseren af Kvalme: Hvad vil det sige at skrive? Repræsenterer Roquentins projekt en løsning på den problematiske skelnen mellem 'at fortælle' og 'at leve' uden at blive fanget i et morads af mauvaise $f o i$ ? Hvis det er tilfældet, hvilke grunde tilbyder Kvalme os for at kunne tro på dette som en mulighed? Og på den anden side, er Roquentins bog genstand for Sartres ironi? Hvis det er tilfældet, hvad betyder den ironiske position så i forhold til den kendsgerning, at Sartre selv har skrevet en bog? Som man ser, går problemet i ring; dets logiske struktur er beslægtet med det kretensiske løgnerparadoks. Det er imidlertid ikke et spørgsmål om at pille Kvalme fra hinanden i en logikkens hakkemaskine eller at forvandle cirkelargumentet til en løkke, som man kan klynge Sartre op i; dette er, når det kommer til stykket, et sterilt spil, som desuden kan spilles med mange andre moderne forfattere. Spørgsmålet har ikke så meget at gøre med, om Kvalme er uundslippeligt indskrevet i paradokset, men snarere om dens grad af bevidsthed om sin egen paradoksalitet. Skaber den et niveau for selvrefleksiv iagttagelse, der er omfattende nok til at gøre kritikken af fiktion til en selvkritik? Eller søger den stiltiende at proklamere sig selv som 'en anden slags bog', der kan slå bro over kløften mellem fiktion og eksistens, sprog og ting, 'historie' og 'sten'? Det sidste er, som vi har set, en umulig drøm (og også en meget gammel drøm). Det ville være bizart, hvis ikke Sartre, selv om han var forført af drømmen, også var bevidst om dens umulighed; faktisk tillader første sektion af Kvalme næppe nogen anden konklusion. Og alligevel er det ikke sikkert. Kvalme står tøvende over for sine paradokser. Det er en roman, som ikke helt kan beslutte sig til, hvad den er, hvad den gerne ville være, hvad den kunne være. Den er emfatisk (oven i købet på en moraliserende måde) i sine afvisninger, hvor den søger at feje hele fortællingens tradition væk som rester af en borgerlig kultur, der er gået bankerot. Men den er uklar i sine forskrifter, såvel de eksplicitte, som de implicitte. For mange er denne tøven ødelæggende, tegn på en grundlæggende mangel på 
kohærens. Men man kunne muligvis lige så godt argumentere for, at dens forvirring på sin vis tilbyder en eksemplarisk illustration af 'modernismens' dilemmaer; at den - om end noget klodset - netop gennem denne forvirring tager de vanskeligheder ved hornene, som andre, mere sofistikerede romanforfattere kan vige uden om gennem den selvvelbehagelige sikkerhed i en transcendent, alvidende ironi.

Oversat fra engelsk af Martin Zerlang 